\title{
Nutrient Removal by Suspended and Biofilm Microalgae for Treating the Wastewater of Agro-Industrial Pig Farm
}

\author{
Rungnapha KHIEWWIJIT*, Klinpratoom PANYAPING and \\ Pattra WONGPANKAMOL
}

Department of Environmental Engineering, Faculty of Engineering, Rajamangala University of Technology Lanna, Chiang Mai 50300, Thailand

('Corresponding author's e-mail: rungnapha@rmutl.ac.th)

Received: 21 July 2017, Revised: 19 October 2017, Accepted: 5 November 2017

\begin{abstract}
In this study, laboratory-scale suspended and biofilm microalgal systems were constructed under outdoor climatic conditions in Northern Thailand to compare their performances on nutrient nitrogen $(\mathrm{N})$ and phosphorus $(\mathrm{P})$ removal and biomass production from anaerobically digested piggery wastewater. At a cultivation time of 14 days, the results showed that removal efficiencies of nitrogen and phosphorus from digested piggery wastewater in biofilm microalgal system were higher than suspended microalgal system. Biofilm system removed on average of $96 \%$ of TKN-N and $92 \%$ of $\mathrm{PO}_{4}{ }^{3-}-\mathrm{P}$, whereas suspended system removed on average of $84 \%$ of TKN-N and $87 \%$ of $\mathrm{PO}_{4}{ }^{3-}-\mathrm{P}$. Average biomass production achieved $1.17 \mathrm{~g}$ dry weight/day for suspended system, while a lower production of $0.78 \mathrm{~g}$ dry weight/day was found for biofilm system in which possibly due to a long harvesting frequency of every 2-weeks. Meanwhile, biofilm system has an advantage over suspended system with respect to simple biomass harvesting. This combination of findings demonstrates that biofilm microalgal system is more suitable for removing $\mathrm{N}$ and $\mathrm{P}$ from digested piggery wastewater than suspended microalgal system. Besides, biomass production in biofilm microalgal system could be further optimized by shorter harvesting frequency and partially harvesting of the biofilm biomass. This study indicates that microalgae offer the potential to recover valuable nutrient resources from piggery wastewater and use biomass for sustainable energy production or other high-value products, which will improve sustainability of agro-industrial wastewater management in the future.
\end{abstract}

Keywords: Digested piggery wastewater (DPW), nitrogen removal, phosphorus removal, suspended microalgae, biofilm microalgae

\section{Introduction}

An agro-industrial wastewater represents the major sources of water pollution throughout the world, in particular from agro-industrial pig farm which is one of the world's largest producers of wastewater [1]. Although piggery wastewater is usually treated by anaerobic digestion to produce methane and eliminate pathogens [2], post-treatment of digested piggery wastewater is still needed to further reduce nutrient to meet the discharge guidelines in order to prevent environmental problems such as eutrophication of aquatic system. The commonly techniques used for removing nutrients from digested piggery wastewater are constructed wetland and stabilization pond [3]. However, the techniques of constructed wetland and stabilization pond cannot be considered sustainable and robust due to loss of available nutrient resources, varied possible performances and a large land requirement [4]. Clearly, more efficient, robust, sustainable, and economically competitive solutions for the utilization of valuable resources in digested piggery wastewater are needed. Several technologies have been recently developed for treating digested piggery wastewater, such as an intermittently aerated sequencing batch reactor 
http://wjst.wu.ac.th

(IASBR), membrane bioreactor (MBR) and biofilters [5-7]. However, the main drawbacks with a practical implementation of these technologies are that they consume large amount of energy, which is mainly for aeration, and the valuable nutrient nitrogen $(\mathrm{N})$ and phosphorus $(\mathrm{P})$ are not recovered. Hence, microalgae cultivation in digested piggery wastewater for nutrient removal and recovery has been proposed as the sustainable utilization of water resources [8-11]. This is because digested piggery wastewater contains high nutrient $\mathrm{N}$ and $\mathrm{P}$ that can be used as a cheap source of nutrient to produce valuable microalgal biomass to be used as a feedstock for methane production or even high-value products, such as biofuels and aquaculture feed [12,13]. Moreover, microalgae-based systems in wastewater treatment also have substantial advantages in reductions of aeration energy and $\mathrm{CO}_{2}$ emission, and the potential cost saving as no addition of chemicals is needed [12,14,15].

Microalgae cultivation systems can be generally operated with suspended and non-suspended systems using sub-designs of either open or enclosed to the environment [16]. Suspended microalgal system, where microalgal cells move freely inside the reactor, is the most common used for robust and convenient treatment of wastewater. Nevertheless, current technologies to harvest microalgal biomass are still energy intensive and expensive; therefore, harvesting remains a challenge for practical implementation. For non-suspended system (also known as biofilm system), which is considered as a novel concept for cultivating microalgae, microalgal cells are grown and formed biofilm on the carrier material. With biofilm cultivation system, it can overcome the problem of harvesting as microalgal biomass could be easily removed by scrapping, and moreover, little or no separation of solids and liquid is required before discharging the treated effluent [17,18]. Thus, biofilm microalgal system can be considered as a sustainable and economically competitive solution for wastewater treatment.

In the literature, no information is available about the removal of nitrogen and phosphorus from digested piggery wastewater that can be achieved by biofilm microalgal system. Therefore, the main objective of this study was to explore the feasibility of using a novel microalgae cultivation technology for the removal of nitrogen and phosphorus from digested piggery wastewater, with a focus on 2 different cultivation systems: suspended and biofilm. Results of nitrogen removal, phosphorus removal, microalgal biomass production, and the effect of biomass harvesting that obtained from suspended cultivation system were compared with that of biofilm cultivation system under outdoor climatic conditions of Northern Thailand during the beginning of dry season. Additionally, in this study the removal of organic pollutants will also be observed for further optimization of both suspended and biofilm microalgal systems. The results, which will be obtained from this study, will not only offer an opportunity to develop efficient and sustainable post-treatment for piggery wastewater, but also treatment for other agro-industrial wastewater sources can take advantage of these results because microalgae-based systems are well-known for their simplicity, sustainability, low-cost, and valuable biomass production.

\section{Materials and methods}

\section{Digested piggery wastewater characteristics}

The anaerobically digested piggery wastewater was collected from a mesophilic anaerobic digester in a local pig farm, which located in Chiang Mai Province, the Northern region of Thailand. This pig farm was considered as the large-scale pig producers with approximately 60,000 pigs annually sold through markets and produced about $1,000 \mathrm{~m}^{3}$ of wastewater daily. In this local pig farm, a covered lagoon digester for biogas production was used to treat the piggery wastewater. Although the covered lagoon digester gave efficient COD removal from the piggery wastewater, additional post-treatment to further remove nutrient $\mathrm{N}$ and $\mathrm{P}$ was still needed as the quality of digested piggery wastewater could not meet the discharge guidelines, in particular with respect to the concentration of Total Kjeldahl Nitrogen (TKN). In this study, undiluted wastewater effluent from anaerobic digestion for treating piggery wastewater was used to cultivate microalgae. Table 1 gives a summary of the most important characteristics of the digested piggery wastewater used in this study. 
http://wjst.wu.ac.th

Table 1 Characteristics of the digested piggery wastewater fed to suspended and biofilm microalgal systems under outdoor climatic conditions. ( $\mathrm{pH}$ and concentrations are average values and standard deviations are shown between brackets, which calculated from the results of 4 samples.)

\begin{tabular}{llccc}
\hline Parameters & Unit & $\mathbf{1}^{\text {st }}$ cycle & $\mathbf{2}^{\text {nd }}$ cycle & $\mathbf{3}^{\text {rd }}$ cycle \\
\hline $\mathrm{pH}$ & - & $7.52(0.05)$ & $7.46(0.07)$ & $7.56(0.03)$ \\
$\mathrm{TKN}-\mathrm{N}$ & $\mathrm{mg} / \mathrm{L}$ & $425(7)$ & $319(15)$ & $340(15)$ \\
$\mathrm{PO}_{4}{ }^{3-}-\mathrm{P}$ & $\mathrm{mg} / \mathrm{L}$ & $134(4)$ & $140(3)$ & $134(11)$ \\
$\mathrm{TSS}$ & $\mathrm{g} / \mathrm{L}$ & $0.29(0.04)$ & $0.14(0.01)$ & $0.12(0.01)$ \\
Dissolved COD & $\mathrm{mg} \mathrm{COD} / \mathrm{L}$ & $271(10)$ & $246(27)$ & $240(10)$ \\
\hline
\end{tabular}

\section{Photobioreactor setup}

Open photobioreactors were used for microalgae cultivation with 2 different cultivation systems: suspended and biofilm. In this study, both photobioreactors were run at Rajamangala University of Technology Lanna (RMUTL) in Chiang Mai Province, Northern Thailand (1848'34.8"N, 98 $\left.57^{\circ} 10.2^{\prime \prime} \mathrm{E}\right)$ under outdoor climatic conditions during the beginning of dry season, from February to the end of March. During the entire experiments, the data of daily temperatures at RMUTL was obtained from Northern Meteorological Center [19], while the daily solar radiations were obtained from Nakhonthai Automatic Weather Stations [20]. A mixed-species of microalgae was cultivated in a batch mode and inoculated with $1 \% \mathrm{v} / \mathrm{v}$ (approximately $9.4 \mathrm{~g}$ dry weight biomass/L) mixed-microalgae seed from stabilization pond, using as an effluent polishing step, in the same local pig farm that the digested piggery wastewater was collected. In total, 3 batch cycles were operated and each cycle was run with a cultivation time of 14 days to ensure that the maximum microalgal production was achieved [8].

The culture areas were operated in the plastic round basin with a size of $44 \mathrm{~cm}$ (top diameter), 36 $\mathrm{cm}$ (bottom diameter) and $35 \mathrm{~cm}$ height, and had a working volume of $25 \mathrm{~L}$. Mixing of the cultures was performed continuously using an air-pump (Electro-magnetic air pump), which was equipped with an aquarium air stone. For biofilm microalgal system, a patterned sheet with a total area of $0.09 \mathrm{~m}^{2}$ (length $30 \mathrm{~cm}$ and width $30 \mathrm{~cm}$ ) was placed horizontally in the middle of the basin. Microalgal biofilm grew on this flat patterned sheet and a thin layer of liquid of about $2 \mathrm{~cm}$ was flowed over the biofilm, the same as performed in the study of Boelee [21]. This patterned sheet comprised of 3 layers and sewn them together with nylon thread. Material on the top and bottom layers of the patterned sheet was $90 \%$ knitted black shade netting (high-density polyethylene), while material on the middle layer was a coarse scouring pad (Scotch-Brite ${ }^{\mathrm{TM}}$ general purpose scouring pad 105).

\section{Analytical methods}

Samples from the suspended and biofilm batch photobioreactors were first measured $\mathrm{pH}$ using $\mathrm{pH}$ electrode (OHAUS Starter ST5000-B Bench pH Meter, USA) and after that centrifuged at 2,000 rpm for $15 \mathrm{~min}$. The supernatant samples were then collected and analyzed for Total Kjeldahl Nitrogen - nitrogen (TKN-N), phosphate - phosphorus $\left(\mathrm{PO}_{4}{ }^{3-}-\mathrm{P}\right)$ and dissolved chemical oxygen demand (COD) concentrations. The measurements of TKN-N, $\mathrm{PO}_{4}{ }^{3-}-\mathrm{P}$ and dissolved COD were determined according to standard methods [22]. For each cycle, $\mathrm{pH}$ and the concentrations of TKN-N, $\mathrm{PO}_{4}{ }^{3-}-\mathrm{P}$ and dissolved COD were measured at the beginning and at cultivation time of 2 days, 6 days, 10 days, and 14 days in order to explore the changes of these compounds over a similar length of cultivation time.

In this study, the yields of microalgal biomass for both suspended and biofilm microalgal systems were determined using the same method as used by Boelee [21]. In suspended microalgal system, the concentrations of suspended dry weight were analyzed at the beginning and after 14 days of cultivation time by filtering the samples through pre-weighed glass fiber filters (Whatman $\mathrm{GF} / \mathrm{F}, \mathrm{UK}$ ) and drying these filters at $105{ }^{\circ} \mathrm{C}$ for at least $24 \mathrm{~h}$. In biofilm microalgal system, after 14 days of cultivation time the microalgal biomass was harvested using scraping with plastic spoon from the patterned sheet and 
http://wjst.wu.ac.th

analyzed for the total wet weight, dry weight and water content. The concentrations of biofilm dry weight were analyzed by drying the harvested biofilm microalgal biomass at $105{ }^{\circ} \mathrm{C}$ for at least $24 \mathrm{~h}$.

At the end of the $3^{\text {rd }}$ batch cycle, the samples of suspended and biofilm microalgae were observed with a scanning electron microscope (SEM) (JSM-6480LV, JEOL, Japan) in high vacuum mode (acceleration voltage $10-15 \mathrm{kV}$, working distance $10 \mathrm{~mm}$ ).

\section{Results and discussion}

Table 2 summarizes the effect of 2 different types of photobioreactors on the reductions of TKN-N, $\mathrm{PO}_{4}{ }^{3-}-\mathrm{P}$ and dissolved $\mathrm{COD}$ concentrations in the digested piggery wastewater. As can be seen from Table 2, the removal efficiencies of TKN-N and $\mathrm{PO}_{4}{ }^{3-}-\mathrm{P}$ during microalgae cultivation in biofilm system were higher than in suspended system. However, both suspended and biofilm microalgal systems could not reduce dissolved COD concentrations. More details of these results will be described as follows.

Table 2 Effects of 2 different types of photobioreactors on Total Kjeldahl Nitrogen (TKN)-N removal, $\mathrm{PO}_{4}{ }^{3-}-\mathrm{P}$ removal and $\mathrm{COD}$ removal from the digested piggery wastewater. (Concentrations and removal efficiencies are average values. Standard deviations are shown between brackets, which calculated from the results of 3 batch cycles.)

\begin{tabular}{|c|c|c|c|c|}
\hline $\begin{array}{l}\text { Photobioreactor } \\
\text { types and parameters }\end{array}$ & $\begin{array}{l}\text { Concentrations found in the } \\
\text { digested piggery wastewater } \\
(\mathrm{mg} / \mathrm{L})\end{array}$ & $\begin{array}{c}\text { Concentrations found } \\
\text { after treating by } \\
\text { microalgae }(\mathrm{mg} / \mathrm{L}) \\
\end{array}$ & $\begin{array}{c}\text { Removal } \\
\text { efficiency } \\
(\%)\end{array}$ & $\begin{array}{c}\text { Maximum } \\
\text { permitted } \\
\text { value }^{\text {a) }}\end{array}$ \\
\hline \multicolumn{5}{|c|}{ 1. Suspended microalgal system } \\
\hline TKN-N & $369(53)$ & $59(17)$ & 84 & 120 \\
\hline $\mathrm{PO}_{4}^{3-}-\mathrm{P}$ & $139(4)$ & $18(5)$ & 87 & N.A. \\
\hline $\mathrm{pH}$ & $7.52(0.09)$ & $8.95(0.06)$ & - & $5.5-9$ \\
\hline Dissolved COD & $250(26)$ & $281(8)$ & - & $300^{\mathrm{b})}$ \\
\hline \multicolumn{5}{|c|}{ 2. Biofilm microalgal system } \\
\hline TKN-N & $353(55)$ & $13(8)$ & 96 & 120 \\
\hline $\mathrm{PO}_{4}^{3-}-\mathrm{P}$ & $133(6)$ & $11(4)$ & 92 & N.A. \\
\hline $\mathrm{pH}^{4}$ & $7.51(0.03)$ & $7.03(0.11)$ & - & $5.5-9$ \\
\hline Dissolved COD & $254(18)$ & $454(14)$ & - & $300^{\mathrm{b})}$ \\
\hline
\end{tabular}

${ }^{a)}$ Maximum permitted values for effluent standard discharged by pig farm, Standard A - large farm with more than 600 livestock units [23] and N.A. stands for no data available.

b) Values are referred to the parameter of total chemical oxygen demand (COD) [23].

\section{1) Removal of nitrogen and phosphorus from the digested piggery wastewater}

\section{1) TKN-nitrogen removal}

Figure 1 shows the removal of TKN-N from the digested piggery wastewater by suspended and biofilm microalgal systems. The results clearly show that both suspended and biofilm microalgal systems were possible to remove TKN in the digested piggery wastewater to the target permitted value of $120 \mathrm{mg}$ TKN-N/L [23]. At a cultivation time of 14 days, the average concentrations of TKN-N, which calculated from the results of 3 batch cycles, were decreased from $369 \mathrm{mg}$ TKN-N/L to $59 \mathrm{mg}$ TKN-N/L when using suspended microalgal system, whereas these were decreased from $353 \mathrm{mg}$ TKN-N/L to $13 \mathrm{mg}$ TKN-N/L when using biofilm microalgal system. For both systems, average TKN-N removal efficiencies were 84 and $96 \%$ for suspended microalgal system and biofilm microalgal system, respectively.

The TKN decreased through microalgae cultivation can be explained by photosynthetic activity. Nitrogen is an essential element for proteins synthesis and aided the assimilation of phosphorus to produce microalgal biomass [16]. Nitrate $\left(\mathrm{NO}_{3}{ }^{-}\right)$and ammonium $\left(\mathrm{NH}_{4}{ }^{+}\right)$are both potential nitrogen sources for the photosynthetic of microalgae and converted these into the organic nitrogen as also 
http://wjst.wu.ac.th

reported in other studies $[8,24]$. However, it is important to note that concentration of TKN is defined as the sum of organic nitrogen and ammonium-nitrogen [22].

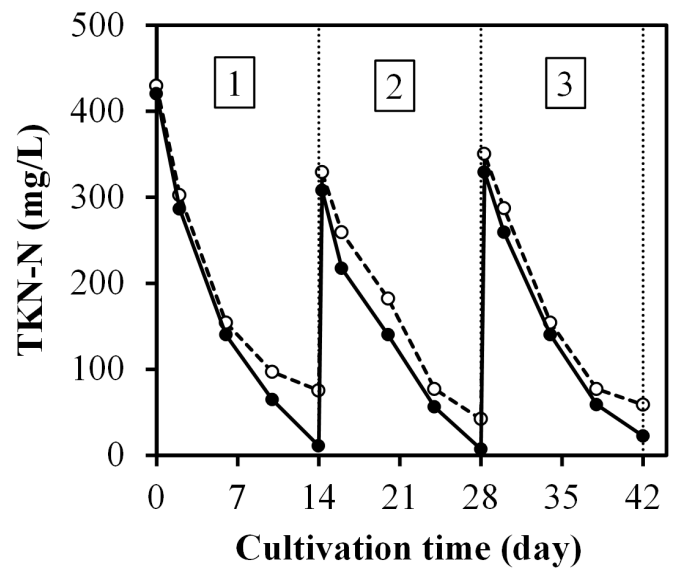

Figure 1 Concentrations of TKN-N during microalgae cultivation batch cycles 1 - 3 of the digested piggery wastewater using $(\circ)$ suspended system and $(\bullet)$ biofilm system. Numbers in the box indicate the cycle and $(\cdots)$ indicates harvesting time.

\section{2) Phosphate-phosphors removal}

In addition to nitrogen source, phosphorus is also required for microalgal growth and other mechanisms, for examples, synthesis of ribosomal RNA and energy transport [16]. Figure 2 shows the removal of phosphate-phosphorus $\left(\mathrm{PO}_{4}{ }^{3-}-\mathrm{P}\right)$ from the digested piggery wastewater by suspended and biofilm microalgal systems.

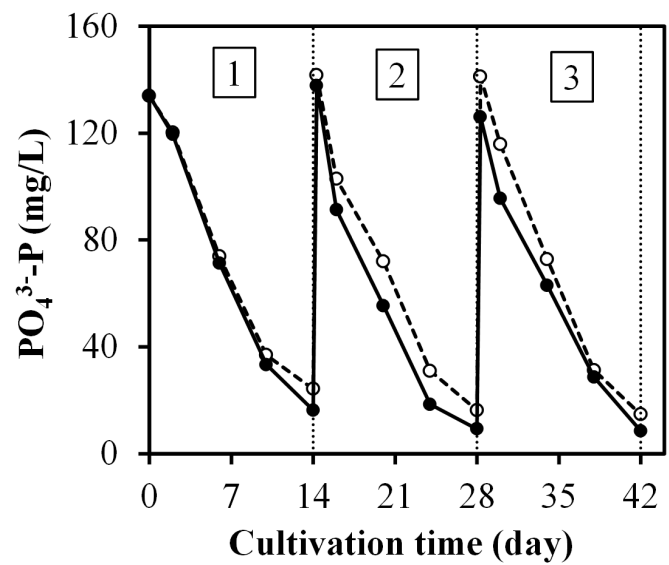

Figure 2 Concentrations of $\mathrm{PO}_{4}{ }^{3-}-\mathrm{P}$ during microalgae cultivation batch cycles $1-3$ of the digested piggery wastewater using $(\circ)$ suspended system and $(\bullet)$ biofilm system. Numbers in the box indicate the cycle and $(\cdots)$ indicates harvesting time. 
http://wjst.wu.ac.th

Similar to the removal of TKN-N, the suspended and biofilm microalgal systems can achieve good removal of $\mathrm{PO}_{4}{ }^{3-}-\mathrm{P}$ from the digested piggery wastewater. At a cultivation time of 14 days, average $\mathrm{PO}_{4}{ }^{3-}-$ $\mathrm{P}$ removal efficiency of $87 \%$ was found for suspended microalgal system with an average $\mathrm{PO}_{4}{ }^{3-}-\mathrm{P}$ concentration of $18 \mathrm{mg} \mathrm{PO}_{4}{ }^{3-}-\mathrm{P} / \mathrm{L}$ in the effluent, while a higher removal efficiency of $92 \%$ was found for biofilm microalgal system with an average $\mathrm{PO}_{4}{ }^{3-}-\mathrm{P}$ concentration of $11 \mathrm{mg} \mathrm{PO}_{4}{ }^{3-}-\mathrm{P} / \mathrm{L}$ in the effluent. These average $\mathrm{PO}_{4}{ }^{3-}-\mathrm{P}$ removal efficiencies and effluent concentrations were calculated from the results of 3 batch cycles. Although there is currently no permitted value for phosphorus from discharging the treated effluent by agro-industrial pig farm [23], with such a low P concentration after applied the microalgae post-treatment as compared to the $\mathrm{P}$ concentrations found in the digested piggery wastewater, these results suggest that microalgae-based treatment becomes a promising candidate technology for removal of nutrient both $\mathrm{N}$ and $\mathrm{P}$ from the digested piggery wastewater. However, further investigation on this microalgae-based treatment is still needed. For examples, the mass balances of $\mathrm{N}$ and $\mathrm{P}$ for treating the digested piggery wastewater in both suspended and biofilm microalgal systems should be considered for future studies. As presented in Table 2, it also shows that the removal efficiencies of $\mathrm{N}$ and $\mathrm{P}$ from the digested piggery wastewater in biofilm microalgal system were higher than suspended microalgal system. This could be explained by the minimization of light limitation and enhancement of $\mathrm{CO}_{2}$ mass transfer when using biofilm microalgal system [25,26]. A higher biomass production can therefore be expected from biofilm microalgal system compared to suspended microalgal system. Nevertheless, it is important to note that possibly because of a long harvesting frequency of every 2weeks, in this study a lower biomass production was found in biofilm microalgal system than that in suspended microalgal system, which will be discussed later.

Based on the results of nutrient removal efficiencies obtained from this study, it is necessary to emphasize that the results are difficult to compare with other previous studies due to differences in, such as, species of microalgae used, cultivation conditions and cultivation purposes (e.g. for wastewater treatment or for lipid production). For examples, Wang et al. [11] reported efficient nutrient removal of both total nitrogen (removal rate of $89.5 \%$ ) and total phosphorus (removal rate of $85.3 \%$ ) from digested piggery wastewater when using an open raceway pond with the improved mixed-microalgae of $C$. vulgaris, C. pyrenoidosa, Haematococcus pluvialis, S. obliquus, S. platensis, and Porphyridium cruentum that performed by ultraviolet irradiation and followed by gradual domestication. Whereas Cheunbarn and Peerapornpisal [8] found that under a batch culture of microalgae $S$. platensis could be efficiently grown on $10 \%$ dilution of digested piggery wastewater with added nutrients consisting of $8.0 \mathrm{~g} / \mathrm{L} \mathrm{NaHCO}_{3}$ and $1.5 \mathrm{~g} / \mathrm{L} \mathrm{NaNO}_{3}$. Moreover, this previous study also found that a maximum treatment was achieved after 12 days of microalgae cultivation and maximum nutrient removal efficiencies were $67 \%$ for phosphate $\left(\mathrm{PO}_{4}{ }^{3-}\right), 49 \%$ for nitrate $\left(\mathrm{NO}_{3}{ }^{-}\right)$and $92 \%$ for ammonium $\left(\mathrm{NH}_{4}^{+}\right)$.

\section{2) Removal of COD from the digested piggery wastewater}

The amount of dissolved COD was also observed through the cultivation cycles, because it was assumed that heterotrophic bacterial populations, which may also present in the cultivation system, can utilize these dissolved organic pollutants to produce new cells [27]. For both suspended and biofilm microalgal systems, after the microalgal seed was added into each batch cycle, the average dissolved COD concentrations were rapidly dropped from 250 to $185 \mathrm{mg} \mathrm{COD} / \mathrm{L}$ and from 254 to $219 \mathrm{mg} \mathrm{COD} / \mathrm{L}$ after the first two days of cultivation time for suspended system and biofilm system, respectively. These decreased COD concentrations most likely can be explained by an adaptation phase for heterotrophic bacteria, which may present in the digested piggery wastewater, to the new environment [28]. However, because in this study only a mixed-microalgae seed was added at the beginning of each cycle, as well as the operational parameters were performed preferable for microalgal growth and not for heterotrophic bacterial growth. Therefore, only microalgae continue to grow in the systems. Other possible reasons that could be explained an increase in dissolved COD was due to the increased rates of endogenous respiration of microalgae and the significant released of organic matters from dense microalgal cultures [29].

As expected, in this study the results also show that the concentrations of dissolved COD were continually increased after 2 days of each cultivation cycle. In particular after 6 days of each cultivation cycle, the average dissolved COD concentrations were increased from 214 to $281 \mathrm{mg} \mathrm{COD} / \mathrm{L}$ at end of 
http://wjst.wu.ac.th

cycle for suspended microalgal system, and moreover, the average dissolved COD concentrations were increased from 322 to $454 \mathrm{mg}$ COD/L when using biofilm microalgal system. Such a high increase of COD concentrations in biofilm microalgal system is most likely caused by the dead microalgal cells that fallout into the liquid when the biofilm gets too thick, leading to limitation of photosynthesis [21,29]. These results indicate that the application of microalgae cultivation for treating the digested piggery wastewater was not able to remove organic pollutants. Therefore, in order to sufficiently remove nutrient and COD in the digested piggery wastewater, a mixture of microalgal-bacterial cultures is suggested [30]. However, the effects of microalgal species on bacterial community, and nutrients/COD ratios should be further investigated and optimized. As reported in the study of Lee et al. [28], the concentrations of dissolved COD were increased after 5 days of cultivating the mixed cultures of microalgae and bacteria on municipal wastewater, which caused by nitrogen limitation and thus bacterial growth was inhibited.

\section{3) Microalgal biomass production and harvesting}

Recently, microalgal biomass is considered as a potential substrate for biogas production as alternative source of renewable energy and for other high-value products. For examples, Ji et al. [9] used microalgae Scenedesmus obliquus to remove nutrient from diluted piggery wastewater and found that at $40 \%$ concentration of digested piggery wastewater, which reduced initial total nitrogen down to 520 $\mathrm{mg} / \mathrm{L}$, gave the most effective for microalgal growth and lipid production that could be used as biofuel feedstock. A review study of González-Fernández et al. [31] also reported that the methane production yield produced from anaerobic digestion of Chlorella and Scenedesmus can be varied from 0.09 - $0.32 \mathrm{~L}$ $\mathrm{CH}_{4} / \mathrm{g} \mathrm{VS}$, depending on operational parameters of such as temperature, reactor type and retention time. However, it is important to note that this methane production yield can still be increased when a pretreatment of microalgae, such as mechanical, sonication/ultrasound and thermal analysis, will be applied. As reviewed by Montingelli et al. [15], methane production could be enhanced by 100 and $110 \%$ when applied ultrasonic and high pressure thermal hydrolysis with lipid extraction as a pre-treatment step of Scenedesmus, respectively. Moreover, microalgae cultivated in digested piggery wastewater could also contribute to enhance sustainable biogas production in pig farm by using the co-digestion of piggery wastewater with microalgal biomass [32]. This implies that microalgae treatment becomes even more attractive to promote sustainable utilization of valuable nutrient resources from piggery wastewater and use biomass for producing high value products. Before making the best use of microalgae for posttreatment of the digested piggery wastewater, the effects of different cultivation systems on microalgal biomass production rate and harvesting were studied. The results are shown as follows.

\section{1) Microalgal biomass production in suspended system}

Table 3 shows the results of net dry weight (DW) yield and biomass production rate for suspended microalgal system. After 14 days of microalgae cultivation, the net DW biomass yield achieved $0.39,0.79$ and $0.78 \mathrm{~g} \mathrm{DW} / \mathrm{L}$ for the cycle 1 , cycle 2 and cycle 3, respectively, and these would translate to an average net DW biomass yield of $0.65 \mathrm{~g} \mathrm{DW} / \mathrm{L}$. Moreover, an average of biomass production rate of 1.17 $\mathrm{g} \mathrm{DW/day} \mathrm{was} \mathrm{observed} \mathrm{for} \mathrm{suspended} \mathrm{system.} \mathrm{However,} \mathrm{apparently} \mathrm{the} \mathrm{separation} \mathrm{of} \mathrm{microalgal} \mathrm{biomass}$ production and treated effluent is needed before discharging the treated effluent into surface waters using, for examples, centrifugation, filtration and flocculation [33]. Consequently, suspended microalgal system would require a higher operational cost for biomass harvesting than using biofilm system [34].

\section{2) Microalgal biomass production in biofilm system}

In this study, the biofilm microalgal batch cultivation was harvested every 14 days or 2-weeks. For each harvesting, the entire biofilm microalgal biomass was harvested by scraping with plastic spoon from the microalgal patterned sheet. Figure 3 shows the sample of half biofilm harvested from the patterned sheet and the harvested microalgal biomass. In total, the microalgal biomass was harvested 3 times. The results of areal wet weight (WW) biomass production, areal dry weight (DW) biomass production, water content, and biomass production rate are shown in Table 4. 
http://wjst.wu.ac.th

Table 3 Microalgal biomass production from suspended system.

\begin{tabular}{ccc}
\hline Numbers of cycle & $\begin{array}{c}\text { Net DW biomass yield } \\
(\mathbf{g ~ D W} / \mathbf{L})\end{array}$ & $\begin{array}{c}\text { Biomass production rate } \\
(\mathbf{g} \text { DW/day })\end{array}$ \\
\hline $1^{\text {st }}$ cycle & 0.39 & 0.69 \\
$2^{\text {nd }}$ cycle & 0.79 & 1.42 \\
$3^{\text {rd }}$ cycle & 0.78 & 1.40 \\
\hline
\end{tabular}

a) Net dry weight biomass yield was calculated as the difference between the microalgal biomass density at the end and at the beginning of each cycle. The concentrations are average values calculated from the results of 3 samples.

Table 4 Microalgal biomass production from biofilm system.

\begin{tabular}{|c|c|c|c|c|}
\hline $\begin{array}{l}\text { Numbers of } \\
\text { cycle }\end{array}$ & $\begin{array}{c}\text { Areal WW biomass } \\
\text { production } \\
\left(\mathrm{g} \mathrm{WW} / \mathrm{m}^{2} / \text { day }\right)\end{array}$ & $\begin{array}{c}\text { Areal DW biomass } \\
\text { production } \\
\left(\mathrm{g} \mathrm{DW} / \mathrm{m}^{2} / \text { day }\right)\end{array}$ & $\begin{array}{l}\text { Water content } \\
(\%)\end{array}$ & $\begin{array}{c}\text { Biomass } \\
\text { production rate } \\
(\mathrm{g} D W / \text { day })\end{array}$ \\
\hline $1^{\text {st }}$ cycle & 7.96 & 3.81 & 52.16 & 0.34 \\
\hline $2^{\text {nd }}$ cycle & 21.71 & 12.01 & 44.69 & 1.08 \\
\hline $3^{\text {rd }}$ cycle & 18.94 & 10.14 & 46.49 & 0.91 \\
\hline
\end{tabular}
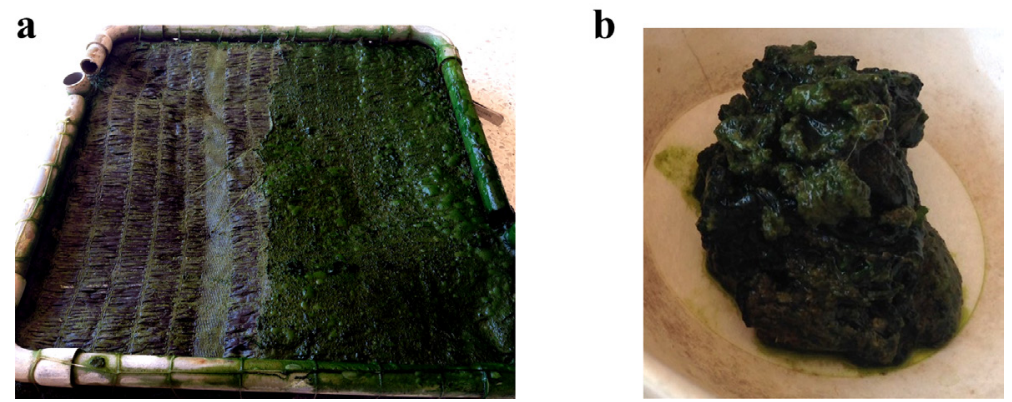

Figure 3 (a) Sample of half biofilm microalgal harvested from the patterned sheet, (b) Sample of harvested biofilm microalgal biomass.

For biofilm system, the areal DW microalgal biomass production achieved 3.81, 12.01 and $10.14 \mathrm{~g}$ $\mathrm{DW} / \mathrm{m}^{2} /$ day for the cycle 1 , cycle 2 and cycle 3 , respectively, which corresponding to the average areal production rate of $8.65 \mathrm{~g} \mathrm{DW} / \mathrm{m}^{2} /$ day. Moreover, an average water content of approximately $48 \%$ was found, which was lower than the results obtained by Boelee et al. [17] and others that generally reported more than $80 \%$ moisture content in wet microalgal biomass [35]. This was probably because biofilm microalgae were grown on the surface of the patterned sheet and only a thin layer of liquid was flowed over the biofilm. This low moisture content in wet microalgal biomass can be advantageous over high moisture content, because water within microalgal biomass would lead to a reduction in cell disruption when the wet biomass is used to produce further products, such as biodiesel [36]. However, this study was observed that the biomass production rates decreased when using biofilm cultivation system as an average biomass production rate was found at $0.78 \mathrm{~g} \mathrm{DW} /$ day, whereas this was $1.17 \mathrm{~g} \mathrm{DW} / \mathrm{day}$ for suspended cultivation system. Apparently, a harvesting frequency of 14 days (2-weeks) cannot maintain the microalgal biofilm formation in the growth phase. Also, it was assumed that microalgal biomass productivity would be decreased with the increasing biofilm thickness [17]. 
http://wjst.wu.ac.th

As demonstrated by the data in Tables 3 and 4, a lower biomass production rate was found in the first cultivation batch as compared to the second and the third batches for both suspended and biofilm microalgal systems. This is likely that the low nutrients uptake was influenced by light and temperature limitations [37]. For examples, as reviewed by Singh and Singh [37], the optimum temperatures ranged from 20 to $30{ }^{\circ} \mathrm{C}$ and the optimum light irradiance varied between 33 and $400 \mu \mathrm{mol} / \mathrm{m}^{2} / \mathrm{s}$ for growth of different microalgae species. In this study, average temperatures for the cycle 1 , cycle 2 and cycle 3 were $24{ }^{\circ} \mathrm{C}$ (min. $14{ }^{\circ} \mathrm{C}$ and $\left.\max .34{ }^{\circ} \mathrm{C}\right), 27^{\circ} \mathrm{C}\left(\min .16{ }^{\circ} \mathrm{C}\right.$ and $\max .37{ }^{\circ} \mathrm{C}$ ) and $29^{\circ} \mathrm{C}\left(\min .19{ }^{\circ} \mathrm{C}\right.$ and $\max$ $39^{\circ} \mathrm{C}$ ), respectively [19]. Moreover, average solar irradiations for the cycle 1 , cycle 2 and cycle 3 were 827,932 and $964 \mu \mathrm{mol} / \mathrm{m}^{2} / \mathrm{s}$, respectively [20]. Considering that only $43 \%$ of the solar radiation is available for the photosynthesis of microalgae [24], this would translate to average solar irradiations used in photosynthesis of 356,401 and $415 \mu \mathrm{mol} / \mathrm{m}^{2} / \mathrm{s}$ for the cycle 1 , cycle 2 and cycle 3 , respectively.

In order to get a better understanding of different forms of microalgal growth, microalgal biomass obtained from the end of cycle 3 both for suspended and biofilm cultivation systems were observed by SEM. Figure 4 depicts the SEM pictures of microalgae grown on the digested piggery wastewater.

a

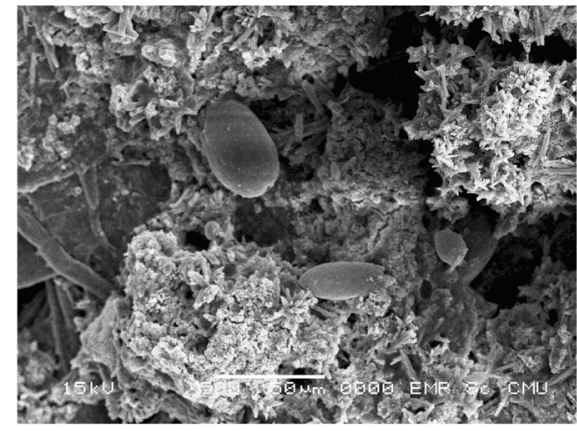

c

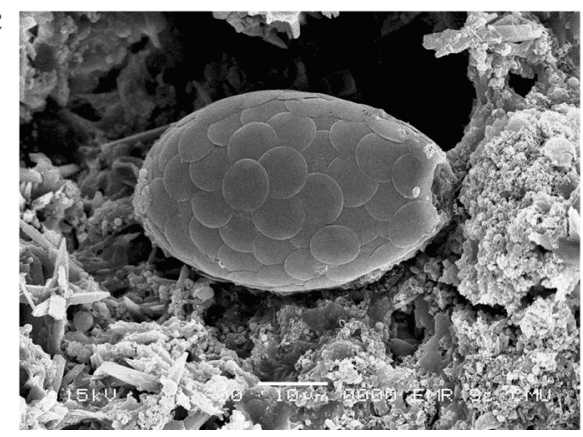

b

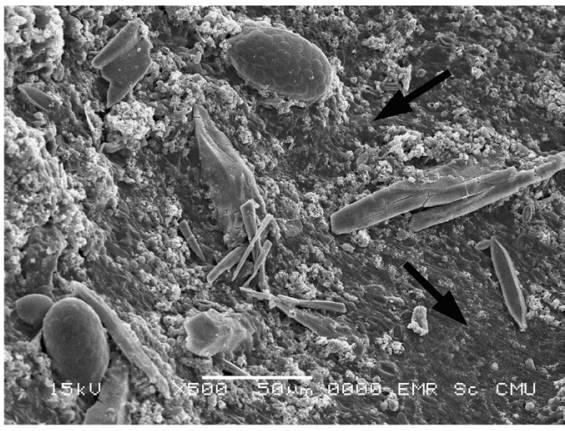

d

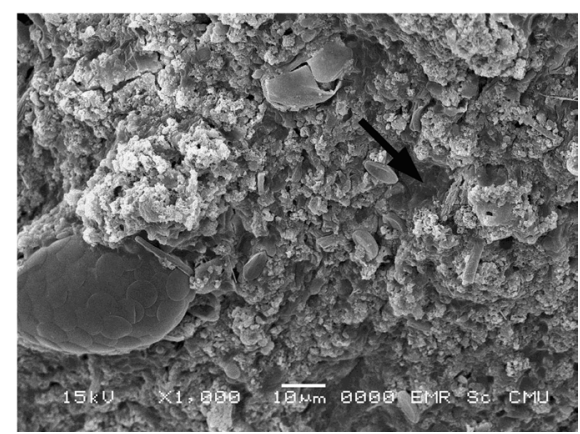

Figure 4 Scanning electron microscope (SEM) pictures of microalgae grown on the digested piggery wastewater using 2 different cultivation systems: (a, c) Suspended microalgae and (b, d) Biofilm microalgae. (Arrows indicate the samples of a matrix of EPS found in biofilm microalgal system.)

As expected, both suspended (Figures 4a and 4c) and biofilm (Figures $\mathbf{4 b}$ and $\mathbf{4 d}$ ) cultivation systems obtained a mixed-species of microalgae. However, in this study the differences in type and density of microalgae population between the 2 cultivation systems, as well as the reasons for their differences remain unclear and ask for future studies. The species of microalgae grown in both suspended and biofilm cultivation systems are necessary to identify. Based on the results of $\mathrm{N}$ and $\mathrm{P}$ removal from the digested piggery wastewater that were found in this study, the species of microalgae would more likely dominate by Chlorella sp., Scenedesmus sp. and pennate diatom for both suspended and biofilm 
http://wjst.wu.ac.th

microalgal systems [10]. In addition, Figures $\mathbf{4 b}$ and $\mathbf{4 d}$ clearly show that microalgal biofilm formation was connected with the aid of extracellular polymeric substances (EPS), which also reported in the study of Boelee [21]. Production of EPS is consisted mainly polysaccharides and additional compounds, such as proteins, nucleic acids and lipids. EPS plays an important role in various aspects of biofilm formation. For examples, EPS help in cohesion within the biofilm and adhesion of microorganism to a surface. Also, EPS influence the exchange of nutrients and help to retain water inside microalgal cells, resulting in a long survival during hot weather and dry months [18].

\section{3) Biomass harvesting in biofilm system}

Based on the results of high increased in dissolved COD concentrations at the end of each cultivation cycle when using biofilm system, a harvesting frequency of every 2-weeks seems to be too long, as well as a harvesting method of scraping entire biofilm seems insufficient to remain the stable biomass production. These findings are also supported by the changes in $\mathrm{pH}$ during microalgae cultivation. For suspended microalgal system, an average $\mathrm{pH}$ in the beginning of cultivation cycle was 7.52; afterwards the $\mathrm{pH}$ was gradually increased through the end of cultivation cycle and ended up with an average $\mathrm{pH}$ of 8.95 (Table 1). However, for biofilm microalgal system, an average $\mathrm{pH}$ in the beginning of cultivation cycle was 7.51, and then the $\mathrm{pH}$ was rapidly increased up to an average of 8.92 after the first 2 days of cultivation time, but after that the $\mathrm{pH}$ was slowly decreased through the end of cultivation cycle and ended up with an average of 7.03 (Table 1). These results are in agreement with the study of Marchello et al. [38], which also found that $\mathrm{pH}$ had a tendency to increase when microalgae were growing due to a reduction of $\mathrm{CO}_{2}$ in the system. Besides, the decreased $\mathrm{pH}$ in biofilm system could be explained by a lower phototrophic activity of microalgae, which possibly caused by the light and/or nutrients limitation. As suggested by the study of Boelee et al. [17], for the post-treatment of municipal wastewater by using biofilm microalgal system, the optimal harvesting frequency was suggested to be once a week and the microalgal biofilm should be partially harvested from the carrier material.

\section{Conclusions}

Sustainable nutrient $\mathrm{N}$ and $\mathrm{P}$ removal from digested piggery wastewater using microalgae was investigated. Laboratory-scale suspended and biofilm microalgal systems were parallel constructed under outdoor climatic conditions in Northern Thailand, and compare their performances on treatment efficiencies and biomass production from digested piggery wastewater. Based on the results obtained from this study, it can be concluded that both suspended and biofilm microalgal systems show efficient nutrient removal and biomass production from digested piggery wastewater, but the removal efficiencies of $\mathrm{N}$ and $\mathrm{P}$ from digested piggery wastewater in biofilm system were higher than suspended system. At a cultivation time of 14 days, biofilm microalgal system removed on an average of $96 \%$ of TKN-N and 92 $\%$ of $\mathrm{PO}_{4}{ }^{3-}-\mathrm{P}$, resulting in good effluent quality with an average of $13 \mathrm{mg}$ TKN-N/L and $11 \mathrm{mg} \mathrm{PO}_{4}{ }^{3-}-\mathrm{P} / \mathrm{L}$. For suspended microalgal system, average removal efficiencies of $84 \%$ of TKN-N and $87 \%$ of $\mathrm{PO}_{4}{ }^{3-}-\mathrm{P}$ were achieved, and moreover, good effluent quality with an average of $59 \mathrm{mg}$ TKN-N/L and $18 \mathrm{mg} \mathrm{PO}_{4}{ }^{3-}$ -P/L was obtained.

Although microalgal biomass production rate in suspended system (1.17 $\mathrm{g}$ dry weight/day) is slightly higher than in biofilm system ( $0.78 \mathrm{~g}$ dry weight/day), growing microalgae in biofilm system advantages in simple harvesting method, as well as, no separation of biomass production and treated effluent would be required before discharging the treated effluent. Therefore, biofilm microalgal system is more suitable for removing $\mathrm{N}$ and $\mathrm{P}$ from digested piggery wastewater than suspended microalgal system and needs further optimization. In particular, regular harvesting with short intervals and partially harvesting of the biofilm biomass should be further explored for increasing biomass production, while maintaining low concentrations of nutrient in the treated effluent. This study not only offers the opportunity to improve sustainability of agro-industrial wastewater treatment for pig farm, but also develop sustainable utilization of agro-industrial wastewater, as microalgal biomass can be used as a feedstock for methane production or other high-value products. 
http://wjst.wu.ac.th

\section{Acknowledgements}

This work was supported by Rajamangala University of Technology Lanna, Chiang Mai, Thailand under the project of Research to Entrepreneur (No. 59R2EENCM201). The authors would like to thank Mr. Khanchit Ngoenkhumkhong, Mr. Jeerayut Panwai and Mr. Worakan Janthiwong for their contribution to the samples analysis.

\section{References}

[1] U.S. Department of Agriculture (USDA). Livestock and poultry: World market and trade. USDA Foreign Agricultural Service. Available at: https://apps.fas.usda.gov/psdonline/circulars/livestock_ poultry.pdf, accessed June 2017.

[2] DP Chynoweth, AC Wilkie and JM Owens. Anaerobic processing of piggery wastes: A review. In: American Society of Agricultural Engineers (ASAE) Annual International Meeting, Orlando, Florida, USA, 1998, p. 1-38.

[3] GJ Liu, D Zheng, LW Deng, Q Wen and Y Liu. Comparison of constructed wetland and stabilization pond for the treatment of digested effluent of swine wastewater. Environ. Tech. 2014; 35, 2660-9.

[4] S Kayombo, TSA Mbwette, JHY Katima, N Ladegaard and SE Jorgensen. Waste stabilization ponds and constructed wetlands design manual. UNEP-IETC with the Danish International Development Agency (Danida), 2005, p. 1-59.

[5] X Song, R Liu, L Chen, B Dong and T Kawagishi. Advantages of intermittently aerated SBR over conventional SBR on nitrogen removal for the treatment of digested piggery wastewater. Front. Environ. Sci. Eng. 2017; 11, 1-10.

[6] X Song, R Liu, L Chen and T Kawagishi. Comparative experiment on treating digested piggery wastewater with a biofilm MBR and conventional MBR: Simultaneous removal of nitrogen and antibiotics. Front. Environ. Sci. Eng. 2017; 11, 1-9.

[7] M Zhang, PG Lawlor, Z Hu and X Zhan. Nutrient removal from separated pig manure digestate liquid using hybrid biofilters. Environ. Tech. 2013; 34, 645-51.

[8] S Cheunbarn and Y Peerapornpisal. Cultivation of spirulina platensis using anaerobically swine wastewater treatment effluent. Int. J. Agric. Biol. 2010; 12, 586-90.

[9] MK Ji, RA Abou-Shanab, JH Hwang, TC Timmes, HC Kim, YK Oh and BH Jeon. Removal of nitrogen and phosphorus from piggery wastewater effluent using the green microalga Scenedesmus obliquus. J. Environ. Eng. 2013; 139, 1198-205.

[10] EG Nwoba, JM Ayre, NR Moheimani, BE Ubi and JC Ogbonna. Growth comparison of microalgae in tubular photobioreactor and open pond for treating anaerobic digestion piggery effluent. Algal Res. 2016; 17, 268-76.

[11] M Wang, Y Yang, Z Chen, Y Chen, Y Wen and B Chen. Removal of nutrients from undiluted anaerobically treated piggery wastewater by improved microalgae. Bioresour. Tech. 2016; 222, 1308.

[12] C Enzing, M Ploeg, MJ Barbosa and L Sijtsma. Microalgae-based Products for Food and Feed Sector: An Outlook for Europe. Joint Research Centre (JRC) Scientific and Policy Reports, 2014.

[13] M Haque, P Bangrak, S Sirisansaneeyakul and W Choorit. Factors affecting the biomass and lipid production from Chlorella sp. TISTR 8990 under mixotrophic culture. Walailak J. Sci. \& Tech. 2012; 9, 347-59.

[14] R Khiewwijit, H Temmink, H Rijnaarts and KJ Keesman. Energy and nutrient recovery for municipal wastewater treatment: How to design a feasible plant layout? Environ. Model. Softw. 2015; 68, 156-65.

[15] ME Montingelli, S Tedesco and AG Olabi. Biogas production from algal biomass: A review. Renew. Sustain. Energ. Rev. 2015; 43, 961-72. 
http://wjst.wu.ac.th

[16] R Whitton, F Ometto, M Pidou, P Jarvis, R Villa and B Jefferson. Microalgae for municipal wastewater nutrient remediation: mechanisms, reactors and outlook for tertiary treatment. Environ. Tech. Rev. 2015; 4, 133-48.

[17] NC Boelee, M Janssen, H Temmink, L Taparavičiūtè, R Khiewwijit, Á Jánoska, CJN Buisman and RH Wijffels. The effect of harvesting on biomass production and nutrient removal in phototrophic biofilm reactors for effluent polishing. J. Appl. Phycol. 2014; 26, 1439-52.

[18] L Katarzyna, G Sai and OA Singh. Non-enclosure methods for non-suspended microalgae cultivation: literature review and research needs. Renew. Sustain. Energy Rev. 2015; 42, 1418-27.

[19] Northern Meteorological Center. Temperature in Chiang Mai $\left({ }^{\circ} \mathrm{C}\right)$ (in Thai). Available at: http://www.cmmet. tmd.go.th, accessed June 2017.

[20] Nakhonthai Automatic Weather Stations. Solar radiation: Weather forecast and monitor site. Available at: http://aws.nakhonthai.net/index.php, accessed June 2017.

[21] Boelee NC. 2013, Microalgal Biofilms for Wastewater Treatment. Ph.D. Dissertation. Wageningen University, Wageningen, The Netherlands.

[22] APHA. Standard Methods for the Examination of Water and Wastewater. $22^{\text {nd }}$ eds. American Water Works Association and Water Environment Federation, Washington DC, 2012.

[23] Pollution Control Department. Notification of the Ministry of Natural Resources and Environment, Effluent Standard for Pig Farm. The Royal Government Gazette, 2005.

[24] NC Boelee, H Temmink, M Janssen, CJN Buisman and RH Wijffels. Scenario analysis of nutrient removal from municipal wastewater by microalgal biofilms. Water 2012; 4, 460-73.

[25] M Gross, D Jarboe and Z Wen. Biofilm-based algal cultivation systems. Appl. Microbiol. Biotech. 2015; 99, 5781-9.

[26] Y Huang, W Xiong, Q Liao, Q Fu, A Xia, X Zhu and Y Sun. Comparison of Chlorella vulgaris biomass productivity cultivated in biofilm and suspension from the aspect of light transmission and microalgae affinity to carbon dioxide. Bioresour. Tech. 2016; 222, 367-73.

[27] PK Mohapatra. Textbook of Environmental Microbiology. IK International Publishing House, New Delhi, India, 2008.

[28] J Lee, J Lee, SK Shukla, J Park and TK Lee. Effect of algal inoculation on COD and nitrogen removal, and indigenous bacterial dynamics in municipal wastewater. J. Microbiol. Biotech. 2016; 26, 900-8.

[29] D Vandamme, I Foubert, I Fraeye and K Muylaert. Influence of organic matter generated by Chlorella vulgaris on five different modes of flocculation. Bioresour. Tech. 2012; 124, 508-11.

[30] C González-Fernández, B Riaño-Irazábal, B Molinuevo-Salces, S Blanco and MC García-González. Effect of operational conditions on the degradation of organic matter and development of microalgae-bacteria consortia when treating swine slurry. Appl. Microbiol. Biotech. 2011; 90, 114753.

[31] C González-Fernández, B Sialve, N Bernet and JP Steyer. Impact of microalgae characteristics on their conversion to biofuel. Part II: focus on biomethane production. Biofuels, Bioprod. Biorefin. $2012 ; 6,205-18$.

[32] S Astals, RS Musenze, X Bai, S Tannock, S Tait, S Pratt and PD Jensen. Anaerobic co-digestion of pig manure and algae: Impact of intracellular algal products recovery on co-digestion performance. Bioresour. Tech. 2015; 181, 97-104.

[33] AI Barros, AL Gonçalves, M Simões and JCM Pires. Harvesting techniques applied to microalgae: a review. Renew. Sust. Energ. Rev. 2015; 41, 1489-500.

[34] M Singh, R Shukla and K Das. Harvesting of Microalgal Biomass. In Biotechnological applications of Microalgae, CRC Press, New York, 2013.

[35] N Mallick, SK Bagchi, S Koley and AK Singh. Progress and challenges in microalgal biodiesel production. Front. Microbiol. 2016; 7, 1019.

[36] H Cao, Z Zhang, X Wu and X Miao. Direct biodiesel production from wet microalgae biomass of Chlorella pyrenoidosa through in situ transesterification. BioMed Res. Int. 2013; 2013, 930686.

[37] SP Singh and P Singh. Effect of temperature and light on the growth of algae species: A review. Renew. Sustain. Energ. Rev. 2015; 50, 431-44. 
http://wjst.wu.ac.th

[38] AE Marchello, AT Lombardi, MJ Dellamano-Oliveira and CWO de Souza. Microalgae population dynamics in photobioreactors with secondary sewage effluent as culture medium. Braz. $J$. Microbiol. 2015; 46, 75-84. 